Proc. Estonian Acad. Sci. Biol. Ecol., 2001, 50, 1, 37-41

\title{
LAND SNAILS IN AN AFFORESTED OIL-SHALE MINING AREA
}

\author{
Raivo MÄND ${ }^{\mathrm{a}}$, Annelie EHLVEST ${ }^{\mathrm{b}}$, and Piret KIRISTAJA ${ }^{\mathrm{a}}$ \\ a Institute of Zoology and Hydrobiology, University of Tartu, Vanemuise 46, 51014 Tartu, Estonia; \\ raivo.mand@ut.ee \\ b Tartu Naturalists’ House, Riia 185A, Tartu 51014, Estonia; anneli@loodusmaja.park.ee
}

Received 21 October 1999, in revised form 2 February 2000

\begin{abstract}
The numbers and species richness of land snails in four $(8,13,23$, and 25 years old) neighbouring pine plantations in an afforested oil-shale mining area were studied. No snails were found in the eight-year-old plantation. In the 13-year-old plantation two species occurred, but the density of individuals was quite low. In the 25-year-old plantation nine snail species were registered. The degree of species richness in older than 20 years pine plantations of the former oilshale mining area was the same as that in the most base-rich deciduous forests of West-Estonian large islands, while the density of individuals was even higher. Since land snails serve as a very important calcium source for many birds, former oil-shale mining areas may easily turn into far more bird-rich habitats than are most other Estonian pine forests.
\end{abstract}

Key words: land snails, calcium, afforestation, former mining area, pine plantations.

\section{INTRODUCTION}

Afforestation of abandoned oil-shale mines in northeastern Estonia was started in 1960. In the mid-1990s, about $70 \%$ of the former mining area was afforested, of which pine plantations covered 83\% (Pae, 1996). Formation of a more or less stable biological community in a recultivated area is a time-consuming process, which depends on the rate and dynamics of different stages of the whole succession. Up to now biological research in Estonian recultivated mines has been focused mainly on plant succession (Pae, 1996). However, in order to plan reuse of such an area in the future, any data applicable in the modelling of the process prove useful. We collected data on land snails in pine plantations of different age in the Sirgala mining area. 
Belonging to decomposition biota, land snails form an important part of terrestrial ecosystems; besides, many animals prey upon them (Gärdenfors et al., 1995). Moreover, it has been shown recently that land snails serve as an important calcium source for a number of forest birds during their breeding period. The calcium content of birds' normal food is usually insufficient for eggshell formation (Graveland \& van Gijzen, 1994), therefore they must collect additional calcium-rich material, such as snail shells, during egg-laying (see Perrins, 1996 for examples). In some oligotrophic forests birds may suffer severe calcium deficiency due to shortage of snails during the egg-laying period (Graveland et al., 1994; Graveland \& van der Wal, 1996; Mänd et al., 1998; Tilgar et al., 1999). The aim of our work was to obtain preliminary data on the numbers and species richness of land snails in pine plantations of abandoned oil-shale mines, as well as to estimate the suitability of such plantations as a breeding habitat for forest birds considering availability of natural calcium sources there.

\section{MATERIAL AND METHODS}

Four pine plantations $(8,13,23$, and 25 years old), situated close (within two kilometres) to each other, were sampled. All samples were collected on 24 July 1996. Two samples were collected from each plantation using a $25 \times 25 \mathrm{~cm}$ quadrat, as in Graveland et al. (1994) and Mänd et al. (1997). One sample was taken from a randomly chosen point in the pine plantation, and the other, $50 \mathrm{~m}$ apart from the former. The second quadrat was placed close to the nearest tree. Herbs, lichens, mosses, and the litter layer plus the top 1-2 $\mathrm{cm}$ of mineral soil were removed from the quadrat. Therefore, although sampling was done in dry hot weather, even the snails residing in the lowest parts of the litter layer were caught. The material was carefully hand-sorted by experienced snail specialists in laboratory conditions using a magnifying glass. All snails (alive individuals as well as empty shells) were counted and identified.

\section{RESULTS}

No snails were found in the eight-year-old plantation. In the 13-year-old plantation snails belonging to two species occurred, but the density of individuals was quite low (four alive and one dead individual were found on two $25 \times 25 \mathrm{~cm}$ quadrats). In the 23-year-old plantation we registered six snail species with a density of 48 alive and 37 dead individuals in two quadrats, and in the 25 -yearold plantation nine species ( 21 alive and 38 dead specimens in two quadrats). Altogether 12 species were registered in the Sirgala pine plantations studied (Table 1). 
Table 1. Snail species registered in pine plantations of the Sirgala oil-shale mining area. Figures stand for the sums of alive and dead specimens in two $25 \times 25 \mathrm{~cm}$ quadrats. No snails were found in the 8-year-old plantation

\begin{tabular}{l|c|c|c}
\hline \multirow{1}{*}{\multicolumn{1}{c}{ Species }} & \multicolumn{3}{c}{ Age of plantation, years } \\
\cline { 2 - 4 } & 13 & 23 & 25 \\
\hline Cochlicopa lubricella & - & - & 11 \\
C. lubrica & - & 17 & - \\
Columella edentula & - & - & 1 \\
Discus ruderatus & - & - & 17 \\
Euconulus fulvus & 2 & 29 & 6 \\
Nesovitrea hammonis & - & 17 & 14 \\
N. petronella & - & - & 5 \\
Punctum pygmaeum & - & 13 & 1 \\
Vallonia costata & - & - & 3 \\
V. pulchella & - & - & 1 \\
Vertigo substriata & - & 1 & - \\
Vitrina pellucida & 3 & 8 & -
\end{tabular}

\section{DISCUSSION}

The studied material is too limited for a reliable modelling of the formation of snail fauna in the above pine plantations. However, it is still possible to draw some important conclusions. The first snails may settle in a plantation at least in the 13th year after the planting of trees, evidently earlier. After settling, both the species richness and density of snails appear to increase rapidly. For instance, in the 13-year-old plantation in Sirgala the number of snail species was the same or probably even higher than in an average Estonian pine forest, where the number of snail species in a $25 \times 25 \mathrm{~cm}$ quadrat usually varies between 0 and 3 . At the same time, the density of snails in such plantations exceeds definitely that observed in most of our pine forests (Mänd et al., 1996, 1997). The species richness in 23-25-year-old pine plantations is approximately the same as in the most base-rich (and hence snail-rich) deciduous forests of West-Estonian large islands, while the density of individuals is even higher than at the latter sites (Mänd et al., 1997). Only some forests, located in the vicinity of large oil-shale or cement works and subjected to permanent atmospheric pollution with base-rich dust, reveal a richer snail fauna than 23-year-old or older pine plantations in a former oil-shale mining area do (Mänd et al., 1996, 1997).

Our results are in good accordance with the results of an investigation of plant succession in the above-mentioned pine plantations (Pae, 1996). In about 7-10 years after the planting of trees the number of plant species increases significantly due to critically altered environmental conditions (shade, accumulation of primary 
litter and decay). The same factors (shade, litter, decay, and higher diversity of food plants) appear definitely very favourable for snails as well.

As one can infer from the results, the base-rich soil in former oil-shale mines is a favourable enough environment not only for plants but also for snails after a certain period of preceding "latency". This will lead to ecologically significant consequences, as far as land snails play a major role in terrestrial ecosystems (see Introduction). Since they serve also as an important calcium source for forest birds during the breeding period, it is likely that former oil-shale mining areas may turn into far more bird-rich habitats than are most other Estonian pine forests.

\section{ACKNOWLEDGEMENT}

The study was partly supported by the Estonian Science Foundation (grant No. 1631).

\section{REFERENCES}

Gärdenfors, U., Waldén, H. W. \& Wäreborn, I. 1995. Effects of soil acidification on forest land snails. Ecol. Bull., 44, 259-270.

Graveland, J. \& Van Gijzen, T. 1994. Arthropods and seeds are not sufficient as calcium sources for shell formation and skeletal growth in passerines. Ardea, 82, 299-314.

Graveland, J., van der Wal, R., Van Balen, J. H. \& Van Noordwijk, A. J. 1994. Poor reproduction in forest passerines from decline of snail abundance on acidified soils. Nature, 368, $446-448$.

Graveland, J. \& van der Wal, R. 1996. Decline in snail abundance due to soil acidification causes eggshell defects in forest passerines. Oecologia, 105, 351-360.

Mänd, R., Veegen, A., Kiristaja, P., Talvi, T., Sepp, R. \& Asi, E. 1996. Ida-Virumaa tööstusheide on tigudele soodne. In XIX Eesti looduseuurijate päev. Kirde-Eesti loodus (Kukk, T., ed.), pp. 69-75. TA Kirj., Tartu-Tallinn.

Mänd, R., Talvi, T., Veegen, A., Kiristaja, P., Sepp, R. \& Asi, E. 1997. Tigude arvukus ja liigirikkus Eesti metsades. In Kaasaegse ökoloogia probleemid: ajalised muutused Eesti eluslooduses ja keskkonnas (Frey, T., ed.), pp. 143-148. Estonian Council of Ecology, Tartu.

Mänd, R., Tilgar, V. \& Leivits, A. 1998. Calcium deficiency as an ecological constraint for Passerines in oligotrophic forests of Estonia. Biol. Cons. Fauna, 102, 345.

Pae, A. 1996. Metsade taastamisest põlevkivikarjäärides ja taimkatte kujunemisest. In XIX Eesti looduseuurijate päev. Kirde-Eesti loodus (Kukk, T., ed.), pp. 65-68. TA Kirj., TartuTallinn.

Perrins, C. M. 1996. Eggs, egg formation and the timing of breeding. Ibis, 138, 2-15.

Tilgar, V., Mänd, R. \& Leivits, A. 1999. Effect of calcium availability and habitat quality on reproduction in Pied Flycatcher Ficedula hypoleuca and Great Tit Parus major. J. Avian Biol., 30, 383-391. 


\title{
MAISMAATEOD PÕLEVKIVIKARJÄÄRI TAASMETSASTATUD ALAL
}

\author{
Raivo MÄND, Annelie EHLVEST ja Piret KIRISTAJA
}

On uuritud maismaatigude arvukust ja liigirikkust neljas kõrvuti asetsevas (8-, 13-, 23- ja 25-aastases) männinoorendikus, mis on rajatud mahajäetud põlevkivikaevandusse. 8-aastasest noorendikust tigusid ei leitud. 13-aastasest männinoorendikust saadi juba kaks liiki tigusid, kuigi isendeid oli vähe. 25-aastases männikus elas vähemalt üheksa liiki tigusid. Põlevkivikaevandustesse rajatud üle 20 aasta vanuste männiistanduste tigude liigirikkus on umbes samal tasemel kui Lääne-Eesti suursaarte kõige kaltsiumirikkamate lehtmetsade oma, isendiline arvukus on aga viimastest isegi üle. Kuna maismaateod on paljudele metsalindudele munemisajal kriitiliselt tähtsaks kaltsiumiallikaks, võivad endised põlevkivikaevandused muutuda koguni linnurikkamateks elupaikadeks kui enamik Eesti männikuid. 